\title{
THE EFFECT OF JOB CRAFTING ON JOB SATISFACTION: A RESEARCH ON TEACHERS
}

\author{
*Sema POLATCI \\ *Fatih SOBACI \\ *Gaziosmanpasa University, Turkey
}

\begin{abstract}
The current study aims to determine the relationship between job crafting and job satisfaction. Data were collected from 239 primary school teachers. The results showed that only the gender and age differentiate the levels of job crafting and job satisfaction. There were no differences in job crafting and job satisfaction levels of the teachers participating in the survey due to other demographic characteristics. The analyses found that, as a on its own behalf job design, job crafting effects job satisfaction positively, and has significant effect on. Results of the regression analyses it was found that job crafting has causal effect on job satisfaction. According to these results, the job satisfaction' of the teachers who are more flexible in functioning and more effective in the decision process will be high and this situation can increase the educational quality. The findings of the study emphasize the need for management to improve the initiatives of teachers on their job. Applied implications of the results are discussed.
\end{abstract}

Keywords: Job Crafting, Job Satisfaction, Regression Analyse.

\section{INTRODUCTION}

The world economy appears to be experiencing serious problems in the last decade. Especially, the effects of the global economic crisis in 2008, which is described as one of the greatest crises of the history of economy, has become a crisis of whole world. It is important for organisations to develop new dynamics in such a way that they can overcome this difficult processes.

Grant and Parker (2009), as a consequence of this, stated that the needs related to compatibility and proactiveness for organisations and employees are increasing. At the same time, organisations have to do more with fewer people when there is less opportunity to make changes in jobs. This means a higher workload and a need for more efficient work (Heuvel et al., 2015: 511-512). It is also, important that employees are satisfied with the work they are doing from the same reasons. Because it is known that job satisfaction, is an important factor in terms of employee performance and organisational winnings.

These needs require proactive employees who are in control of their working lives, creating a healthy and motivating environment for themselves (Heuvel et al., 2015: 512). The study was born in an effort to draw attention to this necessity and to guide it in the best way possible. Because, in recent years, proactive working concepts and practices, business competence and positive results have come to the forefront. The study contributes to better understanding this issue and to helping business stakeholders take advantage of it, in particular to provide a possible increase in job satisfaction. It is thought that the research is in the correct causal of aim when the importance of work is taken into consideration in terms of the lives of the workers and the sustainability of the organisations.

\section{LITERATURE REVIEW AND THEORETICAL FRAMEWORK Job Crafting}

Organisations often argue that the most important resource they have is people. However, the action does not always coincide with the explanations. It has become widespread for managers to manage or control the creativity of their employees, to engage in obstacles or other behaviours that would cause an employee to be deprived of initiative. Because of this need, the concept of "job crafting" has been developed in 2001, through the research by Professor Amy Wrzesniewski of the Yale University School of Management and Professor Jane Dutton of the University of Michigan Business School.

Job crafting is defined as physical and cognitive changes in the tasks or relational restrictions of individuals (Wrzesniewski and Dutton, 2001: 179). Job crafting captures what employees do to redesign 
their own jobs in ways that can foster job satisfaction, as well as engagement, resilience, and thriving at work (Berg et al., 2008: 1). In other words job crafting is defined as the self-initiated changes that employees make in their own job demands and job resources to attain and/or optimize their personal (work) goals (Tims et al., 2012: 173). In essence, business competence is the process by which employees change the boundaries of their tasks with a proactive approach (Wrzesniewski et al., 2013: 283) it can also be referred to as a redesign approach (as well as top-down approaches) that organisations can use to improve their work (Demerouti and Bakker, 2014: 429). For this reason, job crafting can be defined as an action and those who undertake this action can be defined as job crafters (Wrzesniewski and Dutton, 2001: 179).

Job crafting is a way to think about job design that puts employees "in the driver's seat" in cultivating meaningfulness in their work (Berg et al., 2013: 2) and it includes shaping job boundaries (physical or cognitive) and/or job-related relational boundaries (Wrzesniewski and Dutton, 2001: 179). It is a recognized reality that employees want to have a certain level of control over their work so they can do their jobs with fondness and higher performance. The need for autonomy, which is one of the needs of human resources today, is precisely the case. Those who work in this context may be able to do their activities within the framework of certain rules, but with their own point of view.

Job crafters form the boundaries that describe their jobs in three fundamental practices. These are called "job crafting practices" (Wrzesniewski et al., 2013, 283; Wrzesniewski and Dutton, 2001: 179-193; Berg et al., 2013: 3): First, job crafters may change the physical or time wise boundaries around the bundle of tasks that they consider to be their job. This is called "task crafting," and it involves "adding or dropping tasks, adjusting the time or labour spent on various tasks, and redesigning direction of tasks". The second form of job crafting relates to relationships. Job crafters may redefine the associational boundaries that define the interpersonal interactions included in performing their jobs. This is called "relational crafting". It involves "creating and/or sustaining relationships with others at work, spending more time with preferred individuals, and reducing or completely avoiding contact with others". To put it another way, relational crafting includes changing how, when, or with whom employees interact with in the execution of their jobs. The third form of job crafting occurs when employees change the cognitive task boundaries of their jobs. Job crafters may reframe the cognitive boundaries that ascribe meaning or purpose to the tasks and relationships that involve their jobs. This is called "cognitive crafting". It contains "employees' efforts to perceive and interpret their tasks, relationships, or job as a whole in ways that change the significance of their work". Changing the view of the job in this way substantially changes how employees approach the job. Three forms of job crafting do not have a mutually exclusive feature, and business competencies can use any assembly of these three forms. As a result, job crafting submits an alternative point of view for understanding basic dynamics of work in organisations such that organisational elements that once seemed fixed are made more complex and dynamic.

Through the features listed above, job crafting is expected to provide a variety of benefits for employees and organisations. There is a lot of research in the literature confirming this expectation. For example, one can say that various studies revealed that job crafting has positive effect on work engagement, performance (Bakker et al., 2012; Tims et al., 2012; Chen et al., 2014; Demerouti ve Bakker, 2014; Lu et al., 2014; Karatepe and Eslamlou, 2017); person-job fit (Bakker, 2011: 268; Tims et al., 2016); organisational commitment and job satisfaction (Ghitulescu, 2007; Leana et al., 2009; Ingusci et al., 2016). Although research on job crafting is still in its infancy, it is worthwhile for organisations to recognize its existence and to manage it such that it has beneficial effects on the employees and the organisation at large (Demerouti, 2014: 237). At the same time, job crafting is seen as a very promising concept in organisational psychology (Tims and Bakker, 2010: 3). As a reflection of this idea, this research focused on the relationship between job crafting and job satisfaction.

\section{Job Satisfaction}

For organisations' competitive advantage and sustainability, contributions made by employees to their organisations are important. As a result of this emphasis, job satisfaction continues to be a remarkable issue for organisations. Ultimately, the assessment of employee attitudes such as job satisfaction has become a common activity in organisations in which management is concerned with the physical and psychological well-being of people (Spector, 1997: 11v).

When people speak of employee attitudes, they usually mean job satisfaction, which describes a positive feeling about a job, resulting from an evaluation of its characteristics (Robbins and Judge: 2014: 37). Job 
satisfaction means a combination of psychological, physical and environmental factors that allow a person to feel satisfied with his/her work (Messina, 2018: 19). Job satisfaction refers to the degree to which people like their job (Spector, 1997: 11v) or an individual's general attitude toward his or her job. A person with a high level of job satisfaction holds positive attitudes toward the job, while a person who is dissatisfied with his or her job holds negative attitudes toward the job (Pranit, 2010: 67). The most-used definition of job satisfaction is developed by Locke (1976: 1304), who defined it as. “... a pleasurable or positive emotional state resulting from the appraisal of one's job or job experiences" (Saari and Judge, 2004: 396).

After these explanations, job satisfaction can be defined as, the meaning that an employee attribute to the work he / she perform and the versatile effect that this meaning has on the employee. The more positive the meaning is, and the stronger the effect is, the higher the job satisfaction the employee will have. So, it can be said that special attention should be paid to the perception of the employee's job in order to increase the job satisfaction. It can be said that to be allowed to design employee's job is one of the ways of positivizing his perception of his job. One of the most effective tools that can be used for this purpose is thought to be job crafting. There are some studies in the literature that show the justification of this thought.

Ingusci and his colleagues (2016) aimed to explore the role of perceived organisational support between job crafting and job satisfaction. As a result of evaluating the data obtained from 263 teachers in the public schools in the south of Italy, it has been seen that the perceived organisational support has a full mediating role between job crafting and job satisfaction. Leana et al. (2009) analysed data from 232 teachers and their assistants and found that collaborative job crafting, especially those with less experienced teachers, have a positive relationship with performance. In addition, collaborative job crafting is associated with higher job satisfaction and organisational commitment and stronger work commitment to teachers with better performance. In the study conducted by Ghitulescu (2007), data were collected from 164 workers and 21 team members. The results of the research showed that individual job crafting increase the level of employees' job satisfaction and organisational commitment.

The purpose of this research is to reveal the relationship between job crafting and job satisfaction, which is associated with many different variables. This relationship, as can be seen from the examples, has been studied in a limited number of studies in the literature. Also, "job crafting" is a new concept, and there is few studies on it in the literature. For this reason, it is believed that this study will contribute to the literature.

The research hypotheses based on the above general explanations and research results are as follows:

H1: Job crafting differs according to the demographic characteristics of the teachers.

H2: Job satisfaction differs according to the demographic characteristics of the teachers.

H3: The job crafting affects job satisfaction positively.

\section{RESEARCH METHODOLOGY Sample and Procedures}

The research sample comprised primary school teachers who are working in the province Tokat in Turkey. A questionnaire form including the scales of the study was prepared to collect the data from a sample of 251 primary school teachers. In terms of data losses and extreme data 12 of them were excluded from the analysis. Thus, the study sample comprised of 239 teachers. Participants' age was in the range from 22 to 63 years with an average of 44 years. And relevant work experience was in the range from 1 to 43 years with an average of 21 years. 136 of them (57\%) were male, and 203 of them (85\%) were bachelor's degree. 76 of the teachers (32\%) provide education for the 4th grade students. The survey was conducted face to face and on a volunteer basis.

\section{Measures}

Original measures translated from English to Turkish. All the questionnaire items were on a 5-point Likert scale ranging 1 (strongly disagree) to 5 (strongly agree). We used The Job Crafting Questionnaire developed by Slemp and Vella-Brodrick (2013: 145-146). This scale has 15 items, 1 to 5 for task crafting, 6 to 10 for cognitive crafting, and 11 to 15 for relational crafting. 
The Job Satisfaction Scale developed by Brayfield and Rothe (1951) was used to measure job satisfaction levels of participants with 5 items. The Cronbach alpha coefficient of original scale was 0.77 . The validity analysis and validation study of this scale were conducted by Bilgin (1995).

The coefficient alpha reliabilities for scales are 0.78 and 0.62 respectively. So, all measures displayed good reliabilities.

\section{Findings}

Descriptive statistics for the variables, and intercorrelations among the variables are presented in Table 1 . The job satisfaction and job crafting averages of participants were found $3.57(\mathrm{sd}=0.55)$ and 3.48 $(s d=0.50)$ respectively. The results showed that participants' job satisfaction levels are higher than job crafting levels. According to the results generated from Table 1, it was seen that job crafting was positively correlated with job satisfaction $\left(\mathrm{r}=.585^{* *}\right)$.

Table 1. Descriptive Statistics and Inter-Correlation Matrix

\begin{tabular}{cccccc}
\hline & & Mean & SD & $\mathbf{1}$ & $\mathbf{2}$ \\
\hline $\mathbf{1}$ & Job Satisfaction & 3.57 & .55 & - & \\
\hline $\mathbf{2}$ & Job Crafting & 3.48 & .50 &, $585 * *$ & - \\
\hline & $* * \mathrm{p}<0.01, \mathrm{n}=239$. & & & &
\end{tabular}

In variance analysis, there is a difference determined between teachers' genders and their job crafting. The results of $t$ test were shown in Table 2. According to the independent sample $t$ test result, female teachers' job crafting level is higher than male ones $(t=.901 ; \mathrm{p}<0.05)$.

Table 2. T-Test Results of Participants Job Crafting

\begin{tabular}{lccccc}
\hline \multicolumn{1}{c}{ Gender } & Mean & SD & df & t & p \\
\hline Female & 3.5189 & .45187 & 235.846 & .901 & $\mathbf{0 . 0 4 3}$ \\
Male & 3.4607 & .52918 & & &
\end{tabular}

In the study, it was examined whether or not the teachers differed according to the different demographic variables. One way ANOVA was performed for this purpose. The results are presented in Table 3. According to the results, it can be said that the teachers exhibit different levels of job crafting according to their age. 41-50 age group have higher job crafting level than the 51+ groups. And also it can be said that the teachers in the 41-50 age group have higher job satisfaction level than the 22-30 age groups.

Table 3. ANOVA Results of Participant

\begin{tabular}{llcccc}
\hline Variables & & Age & $\begin{array}{c}\text { Mean } \\
\text { Difference }\end{array}$ & $\begin{array}{c}\text { Std. } \\
\text { Error }\end{array}$ & p \\
\hline Job Crafting & $41-50$ Age & $51+$ Age &, $21571^{*}$ &, 08072 &, $\mathbf{0 3 4}$ \\
\hline Job Satisfaction & $41-50$ Age & $22-30$ Age &, $44256^{*}$ &, 10798 &, $\mathbf{0 0 1}$ \\
\hline
\end{tabular}

$* \mathrm{p}<0.05$

There were no differences in job crafting and job satisfaction levels of the teachers participating in the survey due to other demographic characteristics. Results of the analyses are presented in Table 4. According to the data in tables 2- 3 and 4, research hypotheses $\mathrm{H} 1$ and $\mathrm{H} 2$ were partially supported. 
Table 4. T-Test and ANOVA Results of Participants

\begin{tabular}{lcc}
\hline \multicolumn{1}{c}{ Demographic Variables } & Job Crafting & Job Satisfaction \\
\hline Work Experience & $\mathrm{F}=1.131 ; \mathrm{p}=0.343$ & $\mathrm{~F}=1.677 ; \mathrm{p}=0.156$ \\
\hline Graduation & $\mathrm{F}=0.312 ; \mathrm{p}=0.732$ & $\mathrm{~F}=2.573 ; \mathrm{p}=0.078$ \\
\hline $\begin{array}{l}\text { Training Offered } \\
\text { Class }\end{array}$ & $\mathrm{F}=2.356 ; \mathrm{p}=0.073$ & $\mathrm{~F}=1.920 ; \mathrm{p}=0.127$ \\
\hline
\end{tabular}

To test the last hypothesis of the study, regression analysis was conducted. Results of the regression analysis were shown in Table 5. First of all, by the regression analysis it was examined the effects of job crafting on job satisfaction. The results of the analysis were significant $(F=123.527, p<0.001)$. Job crafting accounted for approximately $34 \%$ of the total variance of job satisfaction, and job crafting effects the job satisfaction positively $\left(\beta=0.585^{* *}, \mathrm{p}<0.001\right)$. According to the results obtained, H3 hypothesis was supported.

Table 5. Regression Analysis Results

\begin{tabular}{cccccc}
\hline & $\mathbf{R}^{\mathbf{2}}$ & $\mathbf{F}$ & $\mathbf{t}$ & $\boldsymbol{\beta}$ & Sig. \\
\hline Job Crafting & 0.343 & 123.527 & 11.114 & $0.585^{* *}$ & $\mathbf{0 . 0 0 0}$ \\
\hline & & & & &
\end{tabular}

\section{CONCLUSION AND DISCUSSIONS}

There are many studies on job satisfaction, which is one of the fundamental concepts in the literature. However, the concept of job crafting is a new concept in the literature and there is a limited number of studies in this subject. This study has gained attention as one of the first "job crafting" researches in Turkish literature. In the study, it was aimed to evaluate the effect of job crafting on job satisfaction, taking into account the current literature. If the employees have the chance to shape their works in a certain frame in accordance with their requests, job satisfaction level is expected to increase.

The results of the analyses showed that there is a causal relationship between job crafting and job satisfaction. According to the results it has been found out, when the job crafting of the teachers increase, the job satisfaction of them will increase too.

On the other hand, the analyses showed that there was no significant difference between demographic variables except gender and age. According to the variance analysis, female teachers' level of job crafting was found higher than male teachers. It has also been found that there is a difference between some age groups at the levels of job satisfaction and job crafting.

According to these results, it can be said that the job satisfactions of the teachers will increase when the opportunity of job crafting is given. This result is also confirmed by the opinions of the teachers obtained during face-to-face interviews conducted with teachers in the implementation of the survey questionnaire. Teachers think that the reputation of the teaching profession is diminishing. They think that the most important thing that can be done for teachers is to get the teachers to get what they deserve. This reputation will only be possible if education-related regulations are made by themselves and capable trainers. According to these views, teachers want a suitable environment for the application of business skills. It can be said that this process will also increase job satisfaction. As a result, it can be said that the satisfaction level of the teachers will increase in a structure in which the trainers are more effective in the decision making process and more flexible in practice. For this reason, it may be suggested that the authorities that give direction to education policies and practices contribute to this perspective.

The present study was designed as a pioneering study for more comprehensive studies. In further studies, the result of this study can be extended by improving the results and adding different variables to the study. More contributions can be made by conducting research on different sample groups or by adding different variables such as personality, person-job fit, leadership or emotional commitment. 


\section{Journal of Global Strategic Management | V. 12 | N. 1 | 2018-June | isma.info | 0049-056| DOI: 10.20460/JGSM.2018.260 REFERENCES}

Bakker, A. B. (2011),An Evidence-Based Model of Work Engagement, Current Directions in Psychological Science, 20(4), pp.265-269.

Bakker, A. B., Tims, M., and Derks, D. (2012), Proactive Personality and Job Performance: The Role of Job Crafting and Work Engagement, Human Relations, 65(10), pp.1359-1378.

Berg, J. M., Dutton, J. E., and Wrzesniewski, A. (2008), What is Job Crafting and Why Does it Matter?, Retrieved form the website of Positive Organizational Scholarship on April, 15, 2011, pp.1-8.

Berg, J. M., Dutton, J. E., and Wrzesniewski, A. (2013), Job crafting and Meaningful Work, In B. J. Dik, Z. S. Byrne and M. F. Steger (Eds.), Purpose and meaning in the workplace, Washington, DC: American Psychological Association, pp.1-32.

Bilgin, N. (1995), Sosyal Psikolojide Yöntem ve Pratik Çalışmalar, Sistem Yayıncılık, İstanbul.

Brayfield, A. H.,and Rothe, H. F. (1951), An Index of Job Satisfaction, Journal of Applied Psychology, 35, pp.307-311.

Chen, C. Y., Yen, C. H., and Tsai, F. C. (2014), Job Crafting and Job Engagement: The Mediating Role of Person-Job Fit, International Journal of Hospitality Management, 37, pp.21-28.

Demerouti, E. and Bakker, A. B. (2014), Job Crafting, An Introduction to Contemporary, Work Psychology, 1, pp.414-433.

Demerouti, E. (2014), Design Your Own Job Through Job Crafting, European Psychologist, 19 (4), pp.237-247.

Ghitulescu, B. E. (2007), Shaping Tasks and Relationships at Work: Examining the Antecedents and Consequences of Employee Job Crafting, Doctoral dissertation, University of Pittsburgh.

Heuvel, M., Demerouti, E., and Peeters, M. C. (2015), The Job Crafting Intervention: Effects on Job Resources, Self-Efficacy, and Affective Well-being. Journal of Occupational and Organizational Psychology, 88(3), pp.511-532.

Ingusci, E., Callea, A., Chirumbolo, A., and Urbini, F. (2016), Job Crafting and Job Satisfaction in a Sample of Italian Teachers: The Mediating Role of Perceived Organizational Support, Electronic Journal of Applied Statistical Analysis, 9(4), pp.675-687.

Karatepe, O. M., and Eslamlou, A. (2017), Outcomes of Job Crafting Among Flight Attendants, Journal of Air Transport Management, 62, pp.34-43.

Leana, C., Appelbaum, E., and Shevchuk, I. (2009), Work Process and Quality of Care in Early Childhood Education: The Role of job Crafting, Academy of Management Journal, 52(6), pp.1169-1192.

Lu, C. Q., Wang, H. J., Lu, J. J., Du, D. Y., and Bakker, A. B. (2014), Does Work Engagement Increase Person-job Fit? The Role of Job Crafting and Job Insecurity, Journal of Vocational Behavior, 84(2), pp.142-152.

Messina, M. (2018), Job Satisfaction Among Deck Officers. Degree Programme in Maritime Management - Turku

Pranit, K. (2010), Organisational Behaviour. Gyan Publishing House.

Robbins S. P. and Judge, T. A. (2014), Essentials of Organizational Behavior, Thirteenth Edition by Published by Prentice Hall. Copyright (C) 2014 by Pearson Education, Inc.

Saari, L. M., and Judge, T. A. (2004), Employee Attitudes and Job Satisfaction. Human Resource Management, 43(4), pp.395-407.

Slemp, G. R., and Vella-Brodrick, D. A. (2013), The Job Crafting Questionnaire: A new scale to measure the extent to which employees engage in job crafting. International Journal of Wellbeing, 3(2).

Spector, P. E. (1997), Job satisfaction: Application, Assessment, Causes, and Consequences (Vol. 3). Sage publications.

Tims, M., and Bakker, A. B. (2010), Job Crafting: Towards a New Model of Individual Job Redesign, SA Journal of Industrial Psychology, 36(2), pp.1-9. 
Journal of Global Strategic Management | V. 12 | N. 1 | 2018-June | isma.info | 0049-056| DOI: 10.20460/JGSM.2018.260 Tims, M., Bakker, A. B. and Derks, D. (2012), Development and Validation of the Job Crafting Scale, Journal of Vocational Behavior, 80, pp.173-186.

Tims, M., Derks, D., and Bakker, A. B. (2016), Job Crafting and its Relationships with Person-job Fit and Meaningfulness: A Three-wave Study, Journal of Vocational Behavior, 92, pp. pp.44-53.

Wrzesniewski, A. and Dutton, J. E. (2001), Crafting a Job: Revisioning Employees as Active Crafters of Their Work, Academy of Management Review, 26(2), pp.179-201.

Wrzesniewski, A., LoBuglio, N., Dutton, J. E. and Berg, J. M. (2013), Job Crafting and Cultivating Positive Meaning and Identity in Work, In Advances in Positive Organizational Psychology, pp.281-302. 